\title{
Biomedical waste management- an overview
}

\author{
Rabindran \\ Dr. Rabindran, Consultant Neonatologist, Billroth Hospital, Chennai \\ Address for Correspondence: Dr. Rabindran, E mail: rabindranindia@yahoo.co.in
}

\begin{abstract}
Biomedical waste management system is poor in most of the hospital. There is urgent need to increase awareness related with this issue in all the hospital staff.
\end{abstract}

Keywords: Biomedical waste, Colour-coding, Segregation

Biomedical waste is any kind of waste either solid or liquid containing infectious/ potentially infectious materials of medical, laboratory or research origin from activities such as diagnosis, prevention \& treatment of diseases [1]. It consists of human anatomical waste, animal waste, microbiology \& biotechnology waste, waste sharps, discarded medicines \& cytotoxic drugs, soiled waste, liquid waste, incineration ash \& chemical wastes.

Common generators of biomedical waste include hospitals, clinics, medical \& veterinary colleges, blood banks, mortuaries, autopsy centers, biotechnology institutions, research laboratories, home health care \& funeral homes. Hazardous chemicals \& radioactive waste though noninfectious require proper disposal. World Health Organization states that $10 \%$ of hospital waste are infectious \& $5 \%$ are non-infectious but hazardous waste [2]. Biomedical waste has an exposure risk to general public \& occupational hazard to healthcare \& sanitation workers. Management includes waste generation, segregation, collection, reception, transportation, storage, treatment (on-site/ off-site) \& final disposal [3]. Generation includes collection in strong leak-proof containers marked with red biohazard symbol. Discarded sharps are collected in needle boxes. Cleaning devices include brooms, dustpans, mops \& vacuum cleaners. Segregation refers to basic separation of different categories of waste generated at source thereby reducing risks \& cost of handling $\&$ disposal. Handling involves manually moving waste with standard precautions from point of generation, accumulation \& storage locations. Waste should be transported for treatment either in trolleys, or covered wheelbarrow. Storage should not exceed 8-10 hour in big hospitals \& 24 hour in nursing homes. Personnel safety devices like bright yellow heavy-duty rubber gloves, aprons, gowns, suits made of impermeable material like plastic, masks, goggles, face shields, leg coverings, rubber-soled \& anti-skid type boots \& shoe-covers provide protection.
Biomedical waste treatment reduces hazards \& renders it for subsequent handling \& disposal. Incineration, autoclaving, bleach, sodium hydroxide, hypochlorite, alkaline digesters, heat $\&$ microwave are used to sterilize waste. Incineration uses high temperature to convert waste into inert material [4]. Types of incinerators used include multiple hearth type, rotary kiln \& controlled air types. Non-incineration technology includes thermal, chemical, irradiative \& biological methods. Autoclaving uses steam \& pressure \& is of 3 types namely gravity type, pre-vacuum type $\&$ retort type [5]. Microwave Irradiation uses high frequency waves which generate heat to kill pathogens. Plasma Pyrolysis is a process converting organic waste into commercially useful byproducts using plasma-arc. WHO has classified medical waste into 8 categories which include general, pathological, radioactive, chemical, infectious, sharps, pharmaceuticals \& pressurized wastes. In India, Biomedical waste (Management \& Handling) Rules 1998 along with further amendments regulate biomedical waste management. It consists of 6 schedules - I: Category of Biomedical waste, II: Colour coding \& type of container, III: Label for Biomedical waste containers/ bags which should be non-washable \& prominently visible, IV: Label for transport of Biomedical waste containers/ bags, V: Standard for treatment \& disposal, VI: Schedule for waste treatment facilities like Incinerator/ Autoclave/ Microwave System. Operating Standards like combustion efficiency \& Emission Standards are defined.

Schedule -I classifies waste into 10 categories. I- Human anatomical waste- disposed by incineration / deep burial; IIAnimal waste- disposed by incineration / deep burial; IIIMicrobiology \& Biotechnology waste - disposed by autoclaving/ microwaving / incineration; IV- Waste sharpsdisinfected by chemical treatment / autoclaving / microwaving followed by mutilation / shredding; V-Discarded medicine \& cytotoxic drugs - disposed by incineration followed by disposal in secured landfill; VI- Soiled waste - disposed by incineration / autoclaving / microwaving; VII- Solid waste - 
disinfected by chemical treatment / autoclaving / microwaving followed by mutilation / shredding; VIII- Liquid wastedisinfected by chemical treatment $\&$ discharge into drains; IXIncineration ash- disposed in municipal landfill; $\mathbf{X}$ - Chemical waste - discharge into drains for liquids \& secured landfill for solids.

Schedule -II defines colour coding \& type of containers; Yellow is a plastic bag used for category $1,2,3 \& 6$ waste $\&$ treated by incineration/ deep burial. Red is a disinfected container/ plastic bag for category 3,6 \& 7 waste $\&$ treated by autoclaving/microwaving/ chemical treatment. Blue/white translucent is a plastic bag/ puncture proof for category $4 \& 7$ waste $\&$ treated by autoclaving/microwaving/ chemical treatment and destructed by shredding. Black / Green is a plastic bag for category $5,9 \& 10 \&$ disposed in secured landfill. Improper Biomedical waste management leads to environmental pollution, multiplication of vectors like insects, rodents \& worms leading to transmission of diseases like typhoid, cholera, plague, hepatitis \& AIDS. Recycling of disposable syringes, needles, intravenous sets, and glass bottles without proper sterilization leads to hepatitis, tetanus, HIV \& viral diseases. Benefits of biomedical waste management include healthy surroundings, reduction in hospital acquired infections \& cost of infection control, reduction in reuse of infectious disposables $\&$ prevention of occupational health hazards. Awareness about hazards of biomedical waste $\&$ its proper disposal is required for a safe $\&$ healthy future.

Verma $\mathrm{V}$ et al published his study related with awareness and practice of biomedical waste in one of the tertiary care teaching hospital. They observed that still it has lacunae in actions to dispose of its waste and uphold its statutory responsibilities. A policy/ system needs to be formulated/developed based on 'training, educating, creating awareness, reduce, recover, reuse and dispose. [6]

\section{Funding: Nil, Conflict of interest: None. Permission of IRB: Yes}

\section{Reference}

1. Bhagawati G, Nandwani S, Singhal S. Awareness and practices regarding bio-medical waste management among health care workers in a tertiary care hospital in Delhi. Indian J Med Microbiol 2015 Oct-Dec;33(4):580-2. DOI: 10.4103/0255-0857.167323.

2. Glenn, Mc.R \& Grewal, R. Clinical waste in Developing Countries. An analysis with a Case Study of India and a Critique of the Basel TWG Guidelines (1999).

3. Sachdeva S. Biomedical waste and solid waste management draft rules, 2015: A comment. Int $J$ Health Allied Sci 2016;5:129-3. 2DOI: 10.4103/2278-344X.180424 .

4. Gautam V, Thapar R, Sharma M. Biomedical waste management: Incineration vs. environmental safety. Indian J Med Microbiol 2010; 28:191-2.DOI: 10.4103/02550857.66465 .

5. Al-Khatib YA, Ali-Qaroot YA, Ali-Shtayeh MS. Management of healthcare waste in circumstances of limited resources: A case study in the hospitals of Nablus city, Palestine. Waste Manag Res 2009;27:305-12.

6. Verma V, Sharma M. L, Oberoi S, Singh A.Biomedical waste management at tertiary level hospital-Rajindra Hospital [Government Medical College], Patiala-A situational analysis. Int J Med Res Rev 2016;4(11):2054-2058.doi:10.17511 /ijmrr. 2016.i11.26.

\section{How to cite this article?}

